\title{
Nesting Biology of the Leafcutting Bee Megachile minutissima (Hymenoptera: Megachilidae) in Central Saudi Arabia
}

\author{
ABDULAZIZ S. ALQARNI, ${ }^{1}$ MOHAMMED A. HANNAN, ${ }^{1,2}$ VICTOR H. GONZALEZ, ${ }^{3}$ \\ AND MICHAEL S. ENGEL ${ }^{3,4}$
}

Ann. Entomol. Soc. Am. 107(3): 635-640 (2014); DOI: http://dx.doi.org/10.1603/ AN13165

\begin{abstract}
The leafcutting bee Megachile (Eutricharaea) minutissima Radoszkowski is a widely distributed species in the Middle East and a promising pollinator of alfalfa. We provide information on the nest architecture, foraging behavior, phenology, and host plants of a wild population of $M$. minutissima studied between March 2010 and September 2012 in Amariah, a typical desert in central Saudi Arabia. Bees nested in preexisting cavities in the sandy, dry, and loose soil, and built between 2 and 14 leaf-lined brood cells per nest. Females built and provisioned 1-2 cells per day, each consisting of a large oval piece from which the cell cup was made and a small semiround piece that was used as cell cap; however, occasionally small oval pieces were also used in the latter. Cells were built from leaves of Ricinus communis L. (Euphorbiaceae), a locally abundant plant. Both sexes were captured from March to October at flowers of 11 species (10 families), indicating some degree of polylecty as well as either bivoltinism or multivoltinism. We also provide comparative taxonomic comments that will assist bee researchers to easily recognize this species.
\end{abstract}

KEY WORDS alfalfa, Anthophila, foraging, host plant, pollinator

No other family of bees is as diverse in its nesting habits and floral relationships as the family Megachilidae. Nests are excavated in the soil or built in preexisting cavities in the ground, rocks, in pithy stems, galls, or exclusively in arboreal termite nests or abandoned snail shells; nesting materials are quite diverse, including sand, mud, pebbles, resins, masticated plant material, plant trichomes, petals, and leaf pieces. Some taxa are predominantly composed of pollen generalists or polyleges, while others contain mostly pollen specialists or oligoleges, the latter often exhibiting interesting behavioral and morphological specializations to collect and manipulate the pollen (e.g., Müller 1996, Cane et al. 2007, Michener 2007, Gonzalez 2008, Rozen et al. 2010, Alqarni et al. 2012, Gonzalez and Engel 2012, Gonzalez et al. 2012, Gonzalez and Griswold 2013).

Unique among bees is the leaf-cutting behavior exhibited by some taxa in the tribe Megachilini, the most common and diverse megachilid group that contains $\approx 50 \%$ of the species diversity of the family (Michener 2007). Females, particularly in the genus Megachile Latreille sensu Gonzalez (2008), use their mandibles

\footnotetext{
${ }^{1}$ Department of Plant Protection, College of Food and Agriculture Sciences, King Saud University, Riyadh 11451, PO Box 2460, Kingdom of Saudi Arabia.

${ }^{2}$ Current address: 6-125 Cole Road, Guelph, Ontario N1G 4S8, Canada.

${ }^{3}$ Division of Entomology, Natural History Museum, and Department of Ecology \& Evolutionary Biology, 1501 Crestline Dr., Suite 140, University of Kansas, Lawrence, KS 66045.

${ }^{4}$ Corresponding author, e-mail: msengel@ku.edu.
}

to cut pieces of leaves that are then used to build their brood cells. Such a remarkable behavior is often associated with the presence of sharp cutting edges among mandibular teeth and may have started as early as the middle Eocene, as fossils of dicotyledonous leafs with distinctive cuts into the margin suggest (Wedmann et al. 2009). However, leaf-cutting behavior is also exhibited by a few megachiline taxa that lack mandibular cutting edges (Michener 2007).

Megachilini is an economically important group. Some species in Eutricharaea Thomson, an Old World subgenus of Megachile containing > 300 described species (Michener 2007, Gonzalez et al. 2010), have been identified and effectively managed for sustainable agriculture in many parts of the world. For example, the accidental introduction of the alfalfa bee Megachile (Eutricharaea) rotundata F. to North America transformed the alfalfa seed industry and tripled its production. Such a commercial success is largely due to the wealth of knowledge on its biology and natural history that has been developed since its introduction (Pitts-Singer and Cane 2011). Eutricharaea is also a source of invasive species. To date, six species have been identified in the New World (Alvarez et al. 2012, Rasmussen et al. 2012).

Despite the unique biology and economic importance of megachiline bees, the taxonomy of the group is problematic and the biology is unknown for the vast majority of species. As in other group of bees, many species concepts in Megachilini are outdated, identification keys are not available, and when available, they are outdated or poorly illustrated, which makes 
species identification often difficult or even impossible, even for specialists (Gonzalez et al. 2013). Information on behavioral and ecological aspects of the species is highly valuable not only to our knowledge of their adaptations to the environment, but also for a better understanding of their phylogeny and coevolutionary patterns with plants and parasites. For example, the type of substrate and materials, as well as how they use them to build their nests and brood cells, vary greatly among species of Megachile and is rather consistent among species groups (Gonzalez 2008, Gonzalez et al. 2010). Such biological information can also help us to understand extinct bee faunas. For instance, by comparing the size of the cuts left at the margins of fossil leaves by extinct megachilid species with information on extant species, Wedmann et al. (2009) were able to estimate the species composition from the Paleogene of central Europe.

The purpose of this article is to provide information on the nesting biology and host plants of Megachile (Eutricharaea) minutissima Radoszkowski, a widely distributed species in the Middle East that, in recent years, has been investigated as a potential pollinator of alfalfa (Shebl et al. 2008a,b). Taxonomic comments are also provided to facilitate the recognition of this pollinator.

\section{Materials and Methods}

Study Species. As indicated by its name, M. minutissima is a small leafcutting bee $(\approx 6 \mathrm{~mm}$ in body length). Based on the material deposited in the Division of Entomology (Snow Entomological Collections), University of Kansas Natural History Museum (SEMC), Lawrence, KS, the species appears to be widely distributed in the Middle East, occurring in Egypt, Iran, Pakistan, Afghanistan, UAE, Israel, and Saudi Arabia. In Egypt, M. minutissima seems to be bivoltine or multivoltine in trap-nesting conditions, where it is frequently parasitized by the cleptoparasitic bee Coelioxys coturnix Pérez (Megachilini) as well as by the parasitic wasp Sapyga luteomaculata Pic (Hymenoptera: Vespoidae, Sapygidae) (Rozen and Kamel 2007, 2008, 2009). Some details of the egg and larval instars of M. minutissima were provided by Rozen and Kamel (2009).

M. minutissima is morphologically similar to Megachile terminata Morawitz, 1875, a species known from Afghanistan and Pakistan, and thus partially overlapping in distribution with M. minutissima. This species can be distinguished from $M$. terminata primarily by the combination of the following characters: female mesoscutum with coarse, contiguous punctures (shallow and not contiguous in M. terminata); female fifth metasomal tergum with punctures separated by at most a puncture width (separated by at least a puncture width in M. terminata); female terga with apical hair bands narrow, $\approx 0.6-0.7$ times median ocellar diameter (about as wide as median ocellus diameter in M. terminata); male fifth metasomal tergum with integument deeply foveate, particularly on distal half (coarsely punctate, with shallow, large punctures in
M. terminata); and male sixth metasomal tergum with preapical carina multidentate, with several small but distinct teeth, and midapical depression, above the preapical carina deep (preapical carina with teeth reduced laterally and midapical depression shallow).

Study Area. Between September 2010 and September 2012, we observed the nesting biology and foraging behavior of M. minutissima in the area around Amariah, a typical central Saudi Arabian desert environment (Fig. 1). The vegetation is thinly scattered and comprised mostly of native plants, as described in Hannan et al. (2012). Individuals of Prosopis farcta (Banks \& Soland) J. F. Macbr. (Fabaceae), Phragmites australis (Cavanilles) Trinius ex Steudel (Poaceae), and Ricinus communis L. (Euphorbiaceae) as well as some agricultural fields are found in the area.

Nest Collections. In May 2011, we excavated and examined a total of 16 nests using a shovel, pocketknife, and root cutters. Cells were removed with the aid of needles, paint brushes, and forceps. Such nests were selected among 30 nests in the nest aggregation that we marked and followed during $3 \mathrm{~d}$ to guarantee that they were completed before dissection. We considered a nest as completed when the bee added what appears to be a nest plug at the nest entrance. We transferred the nest contents (i.e., nest plug and cells) on a petri dish and transported them in a cooler to the laboratory. We opened the cells with forceps and examined their content under the stereomicroscope. We recorded the number of cells per nest as well as the number and dimensions of leaf pieces used. Most nest features were measured in the field using dial calipers, except for cell dimensions and diameter of their leaf pieces, which were measured for nine cells in the laboratory. Photographs were taken using a digital camera (Nikon E8800, Zoom Nikkor ED 8.9-89 mm).

Nesting and Foraging Behaviors. Nesting activities, namely daily number and duration of foraging trips, were observed in three nests during three consecutive days. Observations began at 0600 hours (sunrise) and lasted until bees stopped foraging or completed a nest. Collections of bees at flowers were done within a radius of $150 \mathrm{~m}$ from the nesting aggregation to determine the most common host plants of $M$. minutissima. To determine the nesting phenology, the nesting area was visited once a week year round between 2011 and 2012. However, nests were excavated in May when the highest bee activity was observed.

Voucher Specimens and Measurements. Specimens from nests and nest structures are deposited in the King Saud University Museum of Arthropods, Plant Protection Department, College of Food and Agriculture Sciences, King Saud University, Riyadh, Kingdom of Saudi Arabia and SEMC. Mean values for nest features and frequency of observed behaviors are given with SDs. We used Pearson correlation analysis to test for association between the number of brood cells and tunnel length, and a two-sample $t$-test to compare average length between unbranched and branched tunnels. Sample sizes varied depending on the availability of the structured measured. 


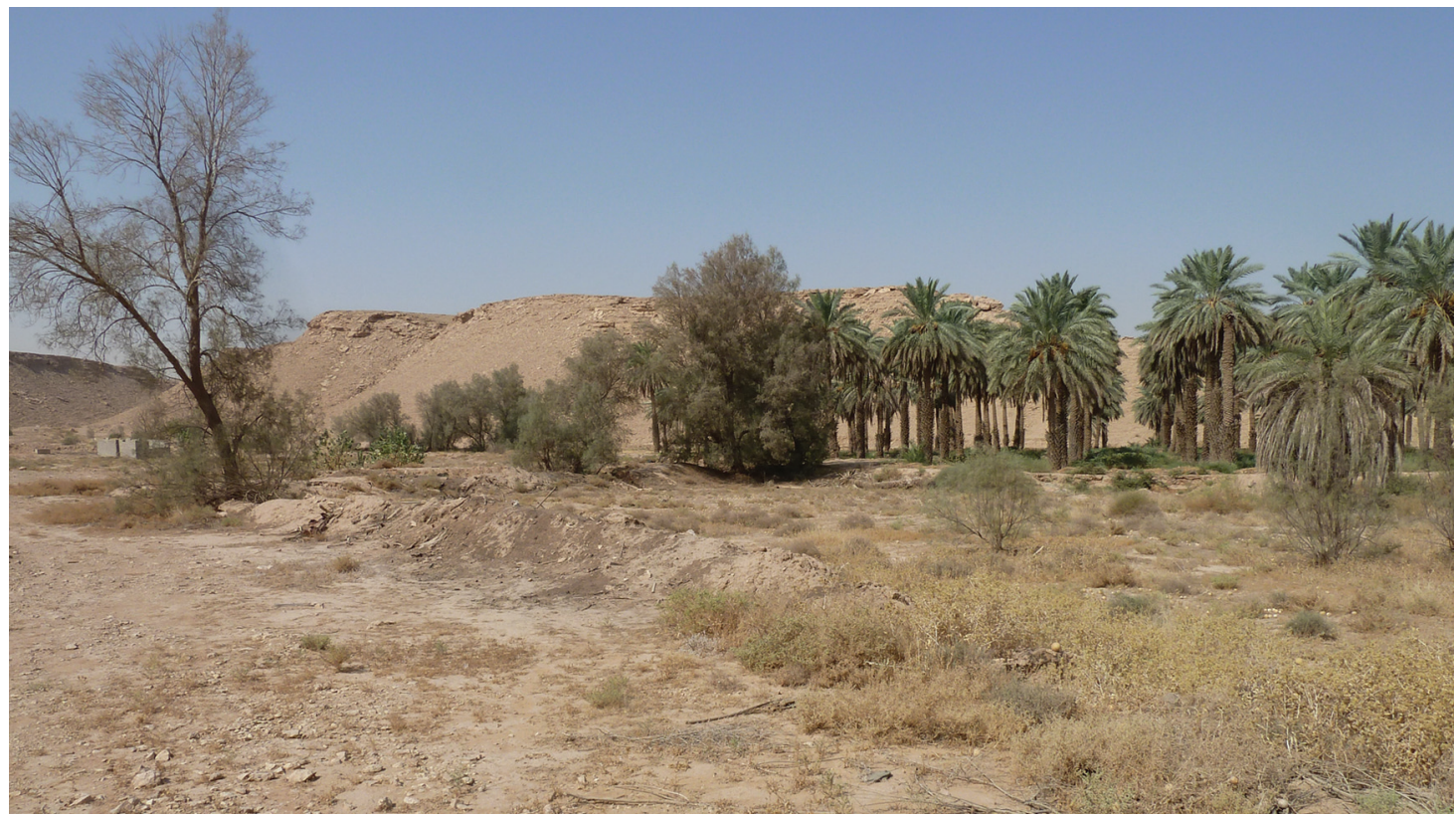

Fig. 1. General habitat at Amariah, Riyadh, Saudi Arabia in September 2011 (photograph by M. S. Engel).

\section{Results}

Nest Architecture. Nests of M. minutissima were found in three aggregations of preexisting holes in the ground on a shaded bank (Fig. 2). Nests occupied an area of $\approx 30 \mathrm{~m}^{2}$ and were concentrated at the upper portion of the bank. Most active nests were located toward the middle of the bank. The type of soil at the nesting site was sandy clay, dry, and loose.

The preexisting holes used by M. minutissima in the soil consisted of tunnels that ranged from 1.7 to $27.5 \mathrm{~cm}$ $(\bar{x}=11.0 \pm 7.4 ; n=16)$ in depth and were oriented either perpendicular or at an angle to the face of the bank. Entrance hole diameter ranged from 4 to $7 \mathrm{~mm}$ $(\bar{x}=5.1 \pm 0.7 ; n=32)$. All tunnels were unbranched, except for six, which had short ramifications and were significantly longer $(t$-test $(6)=3.36 ; P<0.015)$. Half of the completed nests had a nest plug (length: $\bar{x}=$ $4.2 \pm 1.9 \mathrm{~mm} ; n=9$ ) consisting of two types of leaf pieces as distinguished by their shape and size - semirounded and oval (Table 1). Remainder nests did not have a nest plug per se, but instead had a cell that was built close to the entrance and presumably served as a nest plug.

The number of brood cells per nest ranged from 2 to $14(\bar{x}=7.2 \pm 3.6, n=16)$ and it was significantly correlated (Pearson correlation coefficient, $r=0.89$; $P<0.001$ ) with tunnel length. Cells were built serially and tightly fit to the tunnel's wall, as in Fig. 2, but
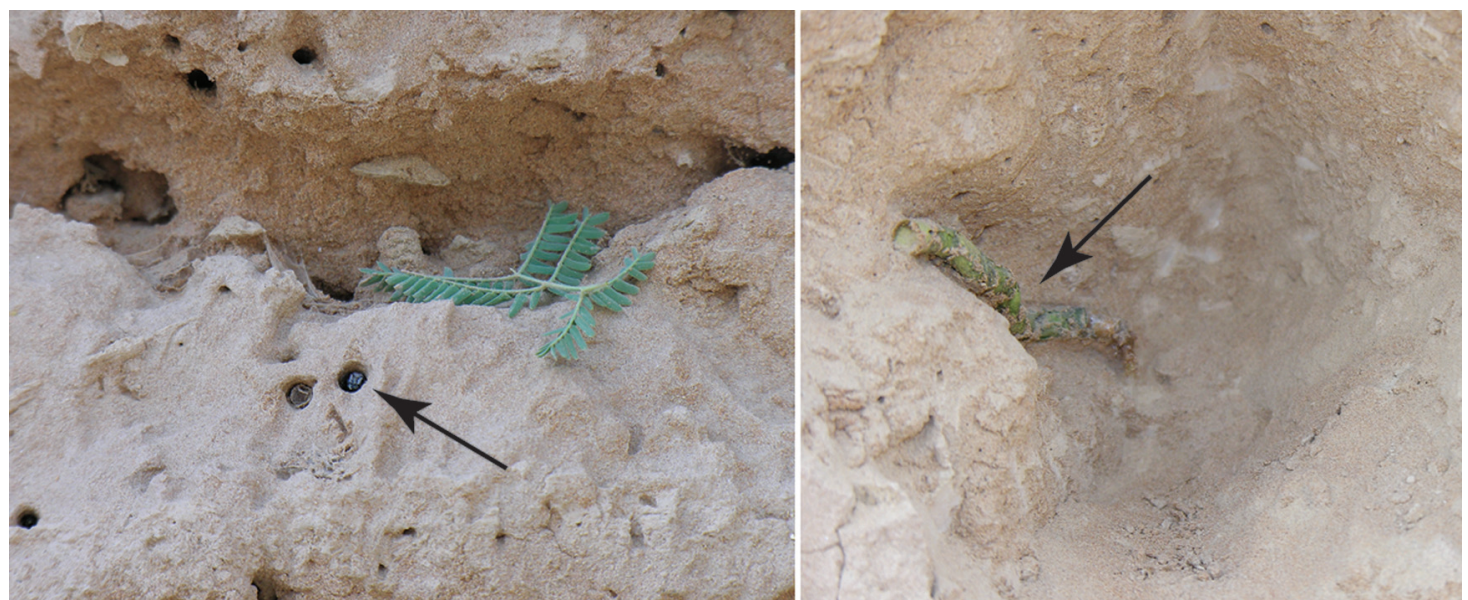

Fig. 2. Nest of M. minutissima in Amariah, Riyadh, Saudi Arabia. Left, arrow points to a nest entrance guarded by a bee; right, arrow points to the leaf-lined cells of an excavated nest (photograph by M. A. Hannan). 
Table 1. Measurement (mm) of leaf pieces used to make brood cells in the nest of M.minutissima

\begin{tabular}{lccc}
\hline \hline \multirow{2}{*}{ Nest feature } & \multicolumn{2}{c}{ Type of leaf piece } \\
\cline { 2 - 4 } & Large oval & Small oval & Semi-round \\
\hline Nest plug & - & $5.3 \pm 0.6 / 3.8 \pm 0.8 ; n=3$ & $3.7 \pm 0.4 / 3.4 \pm 0.5 ; n=11$ \\
Cell cup & $7.0 \pm 0.7 / 4.5 \pm 0.6 ; n=51$ & $5.4 \pm 0.5 / 4.0 \pm 0.4 ; n=11$ & $3.9 \pm 0.28 / 3.8 \pm 0.36 ; n=24$ \\
\hline
\end{tabular}

Means of maximum and minimum widths are given with standard deviations followed by sample size.

occasionally were spaced and not continuous. Brood cells averaged $8.4 \mathrm{~mm}$ in length $( \pm 0.9, n=72)$ and were made of leaf pieces of three different shapes and sizes (large and small ovals, and semirounded) (Table 1). As observed in other species of Eutricharaea (c.f., Medler 1965, Kim 1992), M. minutissima used large oval pieces to make the cell cup and semirounded pieces to make the cell cap, although sometimes they also used small oval pieces for the latter. Leaf pieces were stuck together and the number of each type varied among cells as follows: large oval, $5-8, \bar{x}=6.1 \pm$ $0.9, n=9$; small oval, $0-3, \bar{x}=0.4 \pm 1.0, n=9$; and semiround, $1-4, \bar{x}=2.2 \pm 1.0, n=9$. Bees cut leaf pieces from $R$. communis, one of the common plant species of the area. It was located $\approx 30 \mathrm{~m}$ from the nest aggregation. We did not observe bees cutting leaves from cultivated plants around the nesting area. We found all stages, from eggs to unemerged adults, during the excavations.

Foraging Behavior. Bees began flying as early as 0750 hours (nearly $2 \mathrm{~h}$ after sunrise) and foraged throughout the day until 1600 hours Daily foraging trips varied in number and duration depending on the bee's activity and environmental conditions. Pollencollecting trips ranged from 14 to 26 per day $(\bar{x}=$ $22.0 \pm 6.9 ; n=3$ ) and averaged 6.04 min per trip $( \pm 1.4 ; n=26)$, whereas leaf-collecting trips ranged from 15 to 20 per day $(\bar{x}=16.7, \pm 2.9, n=3)$ and averaged 3.94 min per trip $( \pm 2.0 ; n=16)$. The average time to construct a cell was $65.8 \mathrm{~min}$. After each pollen-collecting trip, a female spent an average of $1.8 \mathrm{~min}$ ( $\pm 0.7 ; n=18$ ) inside the nest depositing the pollen into the cell; however, it remained $>5 \mathrm{~min}$ before changing to leaf collection, suggesting that oviposition occurred during this period. The average time to provision a cell was 132.9 min. It is likely that bees may have carried nectar in their crops during the pollencollecting trips, but we did not test for this. Females of $M$. minutissima can build at least two cells per day, as indicated by a single female that built two cells in a nest, closed it, and moved to start a new one. Antagonistic behaviors among conspecific females were often observed when a female returned to its nest and found it occupied by another bee.

Host Plants. From March to October 2011, we observed both male and females of M. minutissima visiting flowers of 11 plant species of 10 families (Table 2 ), although most females were captured on P. farcta. We did not record whether a female visited a flower for pollen or nectar.

Nest Associates. Although we frequently observed cuckoo wasps of the genus Chrysis L. (Hymenoptera: Chrysididae) flying over the nest aggregation, we did not find this or any other parasite in the cells we reared in the laboratory.

\section{Discussion}

In general, our observations on the nesting biology and foraging behaviors of M. minutissima in the desert of central Saudi Arabia agree with what is known for the few other species of Eutricharaea (e.g., Medler 1965, Klostermeyer and Gerber 1969, Kim 1992). That is, they use preexisting cavities and the bottom of the cells is formed by bending the leaf pieces from the cell cup (Medler 1965, Kim 1992). Noticeable differences from these reports are in the number and size of the leaf pieces used for cell construction as well as in the number and duration of foraging trips. Such differences are related to variation in body size among species, as the larger the bee, the larger the cell and the greater the amount of pollen required for provisioning. Although the aggregation we studied was in the ground, we also found two nests inside stems of $P$. australis (Poaceae) that we set up as trap nests the previous year. This was expected given that M. minutissima is already reared in trap nests in Egypt to be used as a potential pollinator of alfalfa (Shebl et al. 2008a,b).

The fact that brood cells of M. minutissima were only found tightly fit inside the tunnel's walls suggests a preference for cavities of certain diameters as well

Table 2. Plant species and number and sex of individuals of $M$. minutissima collected at flowers in Amariah, Riyadh, Saudi Arabia, from March to October 2011

\begin{tabular}{|c|c|c|c|}
\hline \multirow{2}{*}{ Plant species } & \multicolumn{2}{|c|}{ Bees } & \multirow{2}{*}{$\begin{array}{l}\text { Collection } \\
\text { dates }\end{array}$} \\
\hline & 0 & 우 & \\
\hline \multicolumn{4}{|l|}{ Apiaceae } \\
\hline Coriandrum sativum L. & - & 2 & $2 / \mathrm{VIII}$ \\
\hline \multicolumn{4}{|l|}{ Asteraceae } \\
\hline Pulicaria undulate (L.) C. A. Mey & - & 2 & $17 / \mathrm{V}-12 / \mathrm{VI}$ \\
\hline \multicolumn{4}{|l|}{ Asclepiadaceae } \\
\hline Calotropis procera (Aiton) W. T. Aiton & 1 & 3 & $31 / \mathrm{V}$ \\
\hline \multicolumn{4}{|l|}{ Boraginaceae } \\
\hline $\begin{array}{l}\text { Heliotropium ramosissimum (Lehmann) DC } \\
\text { Fabaceae }\end{array}$ & - & 1 & $10 / \mathrm{III}$ \\
\hline P. farcta (Banks \& Soland) J. F. Macbr & 35 & 13 & $27 / \mathrm{IV}-19 / \mathrm{VI}$ \\
\hline \multicolumn{4}{|l|}{ Lamiaceae } \\
\hline Mentha longifilia (L.) Hudson & 10 & 1 & 12/VII-26/X \\
\hline \multicolumn{4}{|l|}{ Nitrariaceae } \\
\hline Peganum harmala $\mathrm{L}$. & 2 & 1 & 4/IV \\
\hline \multicolumn{4}{|l|}{ Resedaceae } \\
\hline Ochradenus baccatus Delile & 1 & 1 & $12 / \mathrm{X}$ \\
\hline Reseda alba $\mathrm{L}$. & 1 & - & $3 / \mathrm{IV}$ \\
\hline \multicolumn{4}{|l|}{ Tamaricaceae } \\
\hline Tamarix sp. & 1 & 1 & 19/VII-2/VIII \\
\hline \multicolumn{4}{|l|}{ Zygophyllaceae } \\
\hline Zygophyllum coccineum $\mathrm{L}$. & 1 & 1 & $11 / \mathrm{IV}-13 / \mathrm{V}$ \\
\hline
\end{tabular}


as that females might excavate to adjust the tunnel to an appropriate size, if cavities are too narrow. However, we did not observe females digging the soil in the few nests we followed. Some species of Megachile that also nest in preexisting cavities built their cells in any available cavity, even in the absence of confining walls (e.g., Zillikens and Steiner 2004). Thus, our observations suggest that trap-nest tube diameter might be relevant to promote nesting of $M$. minutissima in artificial conditions.

The presence of both sexes of $M$. minutissima at flowers from March to October as well as direct observations at the nest aggregation confirming cell construction and provisioning as early as March, suggest that the species may be either bivoltine or multivoltine. Such observation agrees with reports from Egypt in trap-nesting conditions (Rozen and Kamel 2007, 2008, 2009). Although we did not record the type of source collected at flowers, it seems that M. minutissima is somewhat polylectic, based on the number of plants visited in the area. However, most males and females were collected on P. farcta, suggesting a preference for Fabaceae. Rozen and Kamel (2007) indicated that M. minutissima regularly visits Trifolium alexandrinum $\mathrm{L}$., as well as alfafa (Medicago sativa $\mathrm{L}$.), for pollen. Both species belong to the Fabaceae and thus support our observations. There is future potential for developing this species for alfalfa pollination in Saudi Arabia.

\section{Acknowledgments}

We would like to extend our sincere appreciation to the Visiting Professor Program at the King Saud University for its funding of this research. We are indebted to Yasuo Maeta and two anonymous reviewers for comments and suggestions that improved this work, to Naser Al-Ghosun and Awad M. Awad for assistance in the field, and to the owner and staff of the agricultural farm Mazra'ah Al-Gasim for allowing us to work on their property. V.H.G.'s participation was partially supported by the Department of Biological Sciences, Southwestern Oklahoma State University. This is a contribution of the Division of Entomology, University of Kansas Natural History Museum.

\section{References Cited}

Alqarni, A. S., M. A. Hannan, V. H. Gonzalez, and M. S. Engel. 2012. A new species of Chalicodoma from Saudi Arabia with modified facial setae (Hymenoptera, Megachilidae). ZooKeys 204: 71-83.

Alvarez, L. J., M. Lucia, D. Silvana, J. Pisonero, and A. H. Abrahamovich. 2012. Occurrence of the exotic leafcutter bee Megachile (Eutricharaea) concinna (Hymenoptera: Megachilidae) in southern South America. An accidental introduction? J. Apic. Res. 51: 221-226.

Cane, J. H., T. L. Griswold, and F. D. Parker. 2007. Substrates and materials used for nesting by North American Osmia bees (Hymenoptera: Apiformes: Megachilidae). Ann. Entomol. Soc. Am. 100: 350-358.

Gonzalez, V. H. 2008. Phylogeny and classification of the bee tribe Megachilini (Hymenoptera: Apoidea, Megachilidae), with emphasis on the genus Megachile. Doctoral dissertation, University of Kansas, Lawrence, KS. p. 274.
Gonzalez, V. H., and M. S. Engel. 2012. African and Southeast Asian Chalicodoma (Hymenoptera: Megachilidae): New subgenus, new species, and notes on the composition of Pseudomegachile and Largella. Ann. Zool. 62: 599617.

Gonzalez, V. H., and T. Griswold. 2013. Wool carder bees of the genus Anthidium in the Western Hemisphere (Hymenoptera: Megachilidae): diversity, host plant associations, phylogeny, and biogeography. Zool. J. Linn. Soc. 168: 221-425.

Gonzalez, V. H., M. S. Engel, and I. A. Hinojosa-Díaz. 2010. A new species of Megachile from Pakistan, with taxonomic notes on the subgenus Eutricharaea (Hymenoptera: Megachilidae). J. Kans. Entomol. Soc. 83: 58-67.

Gonzalez, V. H., T. Griswold, C. J. Praz, and B. N. Danforth. 2012. Phylogeny of the bee family Megachilidae (Hymenoptera: Apoidea) based on adult morphology. Syst. Entomol. 37: 261-286.

Gonzalez, V. H., T. Griswold, and M. S. Engel. 2013. Obtaining a better taxonomic understanding of native bees: Where do we start? Syst. Entomol. 38: 645-653.

Hannan, M. A., A. S. Alqarni, A. A. Owayss, and M. S. Engel. 2012. The large carpenter bees of Central Saudi Arabia, with notes on the biology of Xylocopa sulcatipes Maa (Hymenoptera, Apidae, Xylocopinae). ZooKeys 201: $1-14$.

Kim, J. 1992. Nest dimensions of two leaf-cutter bees (Hymenoptera: Megachilidae). Ann. Entomol. Soc. Am. 85: 85-90.

Klostermeyer, E. C., and H. S. Gerber. 1969. Nesting behavior of Megachile rotundata (Hymenoptera: Megachilidae) monitored with an event recorder. Ann. Entomol. Soc. Am. 62: 1321-1325.

Medler, J. T. 1965. A note on Megachile mendica Cresson in trap-nests in Wisconsin (Hymenoptera: Megachilidae). Proc. Entomol. Soc. Wash. 67: 113-116.

Michener, C. D. 2007. The bees of the world, 2nd ed. Johns Hopkins University Press, Baltimore, MD.

Müller, A. 1996. Host-plant specialization in western Palearctic anthidiine bees (Hymenoptera: Apoidea: Megachilidae). Ecol. Monogr. 66: 235-257.

Pitts-Singer, T. L., and J. H. Cane. 2011. The alfalfa leafcutting bee, Megachile rotundata: The world's most intensively managed solitary bee. Annu. Rev. Entomol. 56: 221-237.

Rasmussen, C., A. L. Carríon, R. Castro-Urgal, S. Chamorro, V. H. Gonzalez, T. L. Griswold, H. W. Herrera, C. K. McMullen, J. M. Olesen, and A. Traveset. 2012. Megachile timberlakei Cockerell (Hymenoptera: Megachilidae): Yet another adventive bee species to the Galápagos Archipelago. Pan-Pac. Entomol. 88: 98-102.

Rozen, J. G., Jr., and S. M. Kamel. 2007. Investigations on the biologies and immature stages of the cleoptoparasitic bee genera Radoszkowskiana and Coelioxys and their Megachile hosts (Hymenoptera: Apoidea: Megachilidae: Megachilini). Am. Mus. Novitates 3573: 1-43.

Rozen, J.G., Jr., and S. M. Kamel. 2008. Hospicidal behavior of the cleptoparasitic bee Coelioxys (Allocoelioxys) coturnix, including descriptions of its larval instars (Hymenoptera: Megachilidae). Am. Mus. Novitates 3636: 1-15.

Rozen, J.G., Jr., and S. M. Kamel. 2009. Hospicidal behavior of the cleptoparasitic wasp Sapyga luteomaculata and investigation into ontogenetic changes in its larval anatomy (Hymenoptera: Vespoidea: Sapygidae). Am. Mus. Novitates 3644: 1-24.

Rozen, J. G., Jr., H. Özbek, J. S. Ascher, C. Sedivy, C. Praz, A. Monfared, and A. Müller. 2010. Nest, petal usage, floral preferences, and immatures of Osmia (Ozbekosmia) avo- 
setta (Megachilidae: Megachilinae: Osmiini), including biological comparisons with other osmiine bees. Am. Mus. Novitates 3680: 1-22.

Shebl, M. A., S. M. Kamel, T.A.A. Hashesh, and M. A. Osman. 2008a. Seasonal abundance of leafcutting bees (Megachile minutissima, Megachilidae, Hymenoptera). World J. Agric. Sci. 4: 280-287.

Shebl, M. A., S. M. Kamel, T.A.A. Hashesh, and M. A. Osman. 2008b. The impact of leafcutting bee (Megachile minutissima, Megachilidae, Hymenoptera) (Radoszkowski, 1876) artificial nest sites on seed production of alfalfa, Ismailia, Egypt. Agricultura 5: 33-35.
Wedmann, S., T. Wappler, and M. S. Engel. 2009. Direct and indirect fossil records of megachilid bees from the Paleogene of Central Europe (Hymenoptera: Megachilidae). Naturwissenschaften 96: 703-712.

Zillikens, A., and J. Steiner. 2004. Nest architecture, life cycle and cleptoparasite of the Neotropical leaf-cutting bee Megachile (Chrysosarus) pseudoanthidioides Moure (Hymenoptera: Megachilidae). J. Kans. Entomol. Soc. 77: 193-202.

Received 22 October 2013; accepted 11 March 2014. 